\title{
Benthic grazing impact: coupling and uncoupling in relation to physical forcing
}

\author{
Jens Kjerulf Petersen ${ }^{1, *}$, Marie Maar ${ }^{2}$, Flemming Møhlenberg ${ }^{3}$, Jens E. N. Larsen ${ }^{4}$ \\ ${ }^{1}$ Dansk Skaldyrcenter, Øroddevej 80, 7900 Nykøbing Mors, Denmark \\ ${ }^{2}$ Department of Bioscience, Aarhus University, PO Box 358, Frederiksborgvej 399, 4000 Roskilde, Denmark \\ ${ }^{3}$ DHI Water Environment Health, Agern Allé 5, 2920 Hørsholm, Denmark \\ ${ }^{4}$ Marine Biological Section, Department of Biology, Copenhagen University, Strandpromenaden 5, 3000 Helsingør, Denmark
}

\begin{abstract}
In the shallow micro-tidal cove Kertinge Nor, Denmark, a series of field campaigns were conducted from April 1995 to September 1996. During these campaigns, the effect of benthic grazing on phytoplankton concentrations was studied using a dual approach. In the first approach, the density, size distribution and in situ growth of 3 dominant benthic grazers were determined to assess grazing potential and its realisation. In the second approach, the realised grazing potential was estimated from the decline in area-specific chlorophyll a (chl a) concentrations after breakdown of stratification. Forcing functions were monitored continuously during the field campaigns using meteorological data, current meters, temperature loggers and CTD point measurements. In addition, measurements from a local monitoring program in Kertinge Nor were included in the data analysis. Stratification of the water column in the cove was mainly governed by wind speed and solar radiation and occurred 50 to $75 \%$ of the time. The potential grazing pressure of the benthic suspension feeders varied but was always greater than that required to graze the entire volume of the cove per day. Using both approaches, it was estimated that realised grazing was $\sim 50 \%$ of the potential. The lack of realisation of the grazing potential could be attributed to a lack of mixing of the water column, which resulted in strong vertical gradients in concentrations of $\mathrm{chl}$ a. The primary mode of decoupling between benthic suspension feeders and phytoplankton was the stratification of the water column, which created refuges for the phytoplankton.
\end{abstract}

KEY WORDS: Suspension feeding $\cdot$ Stratification $\cdot$ Ciona intestinalis $\cdot$ Mya arenaria $\cdot$ Mytilus edulis . Wind driven exchange

\section{INTRODUCTION}

A conspicuous element in shallow coastal ecosystems is the presence and often dominance of macrobenthic suspension feeders, such as bivalves, ascidians, sponges and polychaetes. These feeders may reach high densities and have filtering capacities that exceed the total water column up to several times a day (Petersen 2004). Studies have demonstrated that dense natural assemblages of suspension feeders can deplete the overlying water of its content of suspended particulate matter and thus reduce phytoplankton biomass considerably (Frechette et al. 1989, Møhlenberg 1995, Riisgård et al. 1998, Dolmer 2000b).

Investigations of benthic grazing impact have been approached in various ways. A traditional way is to establish clearance capacity of the dominant suspension feeder(s) in the laboratory, determine in situ densities and multiply the 2 estimates (Petersen \& Riisgård 1992, Lemmens et al. 1996, Roditi et al. 1996, Riisgaard et al. 2004). This approach neglects actual mixing conditions in the field and thus tends to overestimate grazing impact. Another approach is to 
enclose a bed of bivalves in a laboratory flume or an in situ tunnel and study factors, e.g. particle depletion, over and across the bed in relation to current speed (Asmus et al. 1992, Butman et al. 1994). With such an approach, the importance of benthic boundary layers and turbulent mixing for the supply of food to benthic suspension feeders is established to the extent that the actual physical conditions are successfully mimicked, but these studies are difficult to extrapolate to entire estuaries, embayments or inlets, especially in micro-tidal areas. The ecosystem approach to benthic pelagic coupling has been to study, on a large temporal or spatial scale, primary production and phytoplankton dynamics in relation to nutrient input and other potentially controlling factors (Cloern 1982, Hily 1991, Caraco et al. 1997) or to study secondary production, e.g. that of bivalves, in relation to ambient conditions (Loo \& Rosenberg 1989). These studies provide an integrated view of benthic pelagic coupling but are by nature not rate specific, and other factors influencing phytoplankton or macro-zoobenthos dynamics cannot be ruled out.

Irrespective of approach, most of these studies underline that the water-processing capacity of benthic suspension feeders is of major importance for plankton dynamics in shallow coastal areas. It has further been demonstrated that the controlling impact of the suspension feeders is dependent on vertical mixing (e.g. (Petersen 2004 and references therein). However, only few studies (Møhlenberg 1995, Riisgård et al. 1996a, 1998, Dolmer 2000a) have dealt in situ with effects of benthic grazing in microtidal areas at a rate-specific level and take into account physical forcing functions. Results from these studies indicate the importance of physical forcing for the nourishment of benthic suspension feeders. Hence, chlorophyll depletion in the bottom layer above suspension feeders could be related to advection under specific conditions (Frechette et al. 1989, Riisgård 1998, Riisgård et al. 1996a, 1998). It has also been demonstrated that bio-mixing created by the exhalent jet of suspension feeders such as ascidians and mussels may be important for mixing and thereby food supply in the near-bed zone (Monismith et al. 1990, Larsen \& Riisgård 1997).

It was our aim to determine how fluctuations in phytoplankton biomass are correlated to physical forcing and feeding by different types of suspension feeders. For this purpose, we applied a dual concept. By 'asking the animals', we investigated the abundance, distribution and clearance capacity of the dominant suspension feeders and thereby determined their clearance potential. In addition, we measured the condition index and in situ growth of benthic suspension feeders to determine the realised clearance. By 'asking the water', we measured physical and biological properties of the water column in vertical profiles along a horizontal transect. In addition, we measured wind, solar radiation and current speed to determine forcing functions for mixingstratification of the water column. The collected data were supplemented with monitoring data collected by local authorities as part of their regular sampling programme. The micro-tidal cove Kertinge Nor, Denmark, was chosen as the study site.

\section{MATERIALS AND METHODS}

Kertinge Nor is a shallow tidal cove with a mean depth of $\sim 2 \mathrm{~m}$, a surface area of $5.5 \mathrm{~km}^{2}$ and a watershed area of $36 \mathrm{~km}^{2}$. The cove exchanges water with the Great Belt through a narrow channel, Kerteminde Fjord (Fig. 1). The tidal amplitude is on aver-

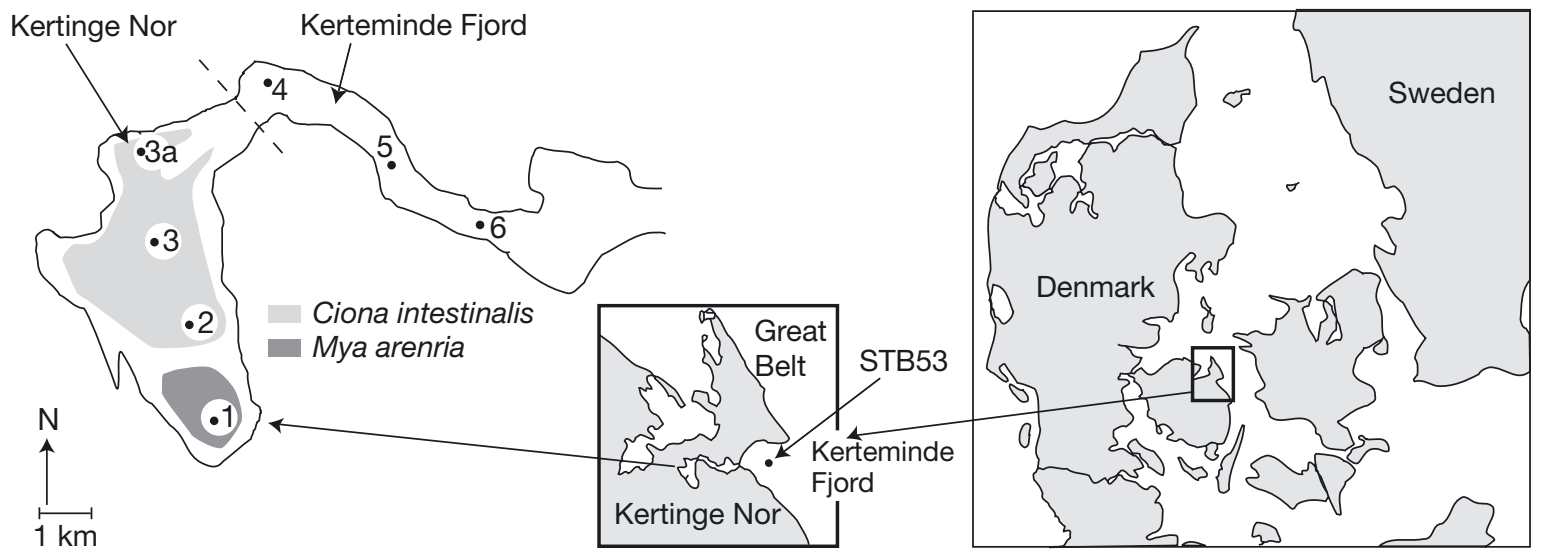

Fig. 1. Sampling stations and area of distribution of Ciona intestinalis and Mya arenaria in Kertinge Nor, Denmark 
age $20 \mathrm{~cm}$, which gives rise to maximum discharges at the fjord entrance of 100 to $200 \mathrm{~m}^{3} \mathrm{~s}^{-1}$. The total freshwater discharge to Kertinge Nor is 0 to $50 \mathrm{l} \mathrm{s}^{-1}$ and is thus negligible with respect to the volume of the fjord system (Møhlenberg \& Jürgensen 1994, Jürgensen 1995). The dominant process of the physical exchange of water between the cove and the Great Belt is considered to be density-driven circulation because salinity variations in Kertinge Nor respond to variations in the Great Belt (Jürgensen 1995). The Great Belt is a transitional area between the Baltic and the North Sea, and accordingly, large fluctuations in salinity (12 to $27 \%$ ) can be observed, giving rise to great horizontal density variations from the inner part of the cove to the mouth (Jürgensen 1995).

Data were collected during 5 campaign periods of 8 to 14 d each in June and September 1995 and April, July and September 1996. In each campaign period, 7 stations were visited daily, 4 stations in the cove and 3 stations in Kerteminde Fjord (Fig. 1). In the county's monitoring programme, 2 stations (1 and 3 ) in the cove and 1 station in the Kerteminde Bight, Great Belt, were visited $\sim 38$ times a year from 1994 to 1996.

\section{Meteorological data}

Meteorological data were collected from the nearby Beldringe airport and from a meteorological station set up $4 \mathrm{~m}$ above the water surface on a platform at Stn 3 (see Fig. 1) during the campaign periods. Solar radiation, wind speed and direction were averaged for every $1 \mathrm{~h}$ at the Beldringe station and every $0.5 \mathrm{~h}$ at the station in Kertinge Nor. In general, there was good agreement between parameters measured at Beldringe and at the platform in Kertinge Nor. Wind speed was, however, on average $18 \%$ lower at Stn 3 compared to Beldringe, mainly due to difference in height of measuring (4 versus $10 \mathrm{~m}$, respectively) and fetch. Largest differences were recorded at northerly and westerly wind directions, where fetch is most reduced in Kertinge Nor. In periods with no wind measurements at Stn 3, weighted wind data collected at Beldringe were used.

\section{Hydrographical data}

Conductivity, temperature and depth (CTD) logger profiles (ME-profiler from Meerestechnik) were taken daily in the campaign periods at 7 stations in Kertinge Nor (Stns 1, 2, 3 and 3a) and Kerteminde Fjord (Stns 4, 5 and 6; Fig. 1). In September 1996, the CTD malfunctioned. In addition, a string with 2 to 4 Ebro temperature loggers was placed at Stns 3 and 4 during each campaign period to identify temperature stratification in Kertinge Nor and Kerteminde Fjord, respectively.

During the campaign periods in September 1995 and 1996 and July 1996, current velocity was measured at Stn 3. Two Valeport model 801 electromagnetic current meters (measuring vol. $25 \mathrm{~cm}^{3}$, sampling rate $1.7 \mathrm{~Hz}$ ) with a $5.5 \mathrm{~cm}$ discus were placed $65 \mathrm{~cm}$ above and level with the bottom, respectively. On a daily basis throughout the campaigns, measurements of current speed in the $\mathrm{x}$ - and y-direction were collected every second and stored on a laptop, and the mean $( \pm 1$ standard deviation [SD]) current speed was calculated for every $100 \mathrm{~s}$. The current meter placed level with the bottom tended to sink into the soft sediment, and only data from the first few days could be used before the current meter was covered with sediment. A rough measure of the turbulent fluctuations for each axis $(x, y)$ was calculated as follows:

$$
T_{U_{i}(x, y)}=\left[\frac{1}{N} \sum_{i=1}^{n}\left(U_{i}-\bar{U}\right)\right] \frac{1}{\bar{U}}
$$

where $U_{i(x, y)}$ is the instantaneous velocity, and $\bar{U}$ is the time-averaged (100 s) velocity.

On 6 dates in June and September 1995, time series of current velocity were also measured at 4 stations ( 2 with dense eelgrass coverage, 1 station with sparse coverage and 1 station without eelgrass) at 5 distances from the bottom. We sampled a total of 80 measurements using a Sensordata ultrasonic current meter (Minilab SD 12) fitted with a 3-axis probe. The instrument is a travel-time-difference current meter with a measuring frequency of up to $30 \mathrm{~Hz}$ and a resolution of $1 \mathrm{~mm} \mathrm{~s}^{-1}$ (see Gytre 1976 for a description of measuring principle). The probe was mounted on a sliding rod fastened to a quadrapod stabilised with weights. Prior to measurement, the quadrapod was deployed at the sediment surface with the sensor oriented upstream and the height of the sensor above the sediment surface adjusted by a diver, who freed any compressed leaves of eelgrass Zostera marina. To prevent interception with eelgrass leaves, the probe was fitted with an open cage (apertures > $20 \mathrm{~mm}$ ) made of $1 \mathrm{~mm}$ stainless steel wire. There was no significant difference in turbulence measurements with and without the cage above the sand bed. Velocity data from the current meter were logged on a portable computer at a rate of $30 \mathrm{~Hz}$. Data were collected for 2 to $3 \mathrm{~min}$ at different heights above the bottom $(10,20,50,100$ and $150 \mathrm{~cm})$. 


\section{Benthic suspension feeders}

The abundance of ascidians Ciona intestinalis was estimated in each campaign period and 2 times in 1994 using SCUBA diving within the area of their occurrence (Petersen \& Riisgård 1992). Along 12 randomized transects, the number of ascidians within a $50 \times 50 \mathrm{~cm}$ frame were counted by the diver at 8 stations. In September 1996, abundance was estimated at 2 additional transects in the southern part of the cove because the area of distribution of ascidians was extended to the southern parts of the cove. Population density was calculated according to Petersen \& Riisgård (1992). The mean size of the population was estimated by measuring the length and dry weight of the tunic and soft parts ( $\left.\mathrm{DW}_{\text {body }}\right)$ of $>200$ ascidians randomly collected on the transects. In each campaign period, the grazing potential of the Ciona population was estimated from the mean individual $\mathrm{DW}_{\text {body, }}$ water temperature and population density. Condition index (CI) was calculated as follows:

$$
\mathrm{CI}=\mathrm{DW}_{\text {body }} / \mathrm{DW}_{\text {total }}
$$

The growth rate $\left(G, \% \mathrm{DW}_{\text {body }} \mathrm{d}^{-1}\right)$ could then be estimated as a linear function of CI for Ciona intestinalis (Petersen et al. 1995, 1997):

$$
G=33.3 \times \mathrm{CI}-14.9
$$

A growth experiment with ascidians was carried out in September 1996 at Stns 2 and 3. Ascidians were deployed 20,50 and $100 \mathrm{~cm}$ above the bottom according to Petersen et al. (1997). Changes in length and $\mathrm{DW}_{\text {body }}$ were determined after $13 \mathrm{~d}$ of deployment. The estimates of $G$ (Eqs. $2 \& 3$ ) were used to calculate the individual (ind.) in situ ingestion ( $I, \mathrm{mg}$ DW d $\mathrm{d}^{-1}$ ind. $^{-1}$ ):

$$
I=G \times B \times G G E^{-1}
$$

where $B$ is the biomass (mg DW ind.$^{-1}$ ), and $G G E=$ 0.33 is the gross growth efficiency (Petersen et al. 1995). The grazing rate $\left(\mathrm{ml} \mathrm{min}^{-1}\right.$ ind. $^{-1}$ ) was estimated as $I$ divided by daily measurements of chlorophyll a (chl a) sampled with siphon mimics using a relation between chl $a$ and carbon ranging from 1:40 to 1:90 depending on the season (Agger et al. 1994). Carbon was converted to DW using a factor of 2.5. The realised grazing was defined as the percentage of estimated grazing relative to the potential grazing.

The abundances of blue mussels Mytilus edulis and soft-shelled clams Mya arenaria were estimated 6 times from fall 1993 to spring 1996 as part of local authority (County of Fyn) regular monitoring. Core samples were taken at 16 stations with 6 replicates, each covering $0.0123 \mathrm{~m}^{2}$. Mussels and clams were counted and their length and biomass measured in each replicate, and average values were calculated for the respective areas of distribution. In addition, mussel abundance and biomass were estimated twice in May 1995 and 1996 using the same method as for ascidians. For clams, individual length and $\mathrm{DW}_{\text {body }}$ were further measured in September 1995 at 7 stations (core samples with 6 replicates of $0.015 \mathrm{~m}^{2}$ ).

For each campaign period, the mussel population grazing potential was estimated from the abundance and individual mean size for 1995 or 1996, respectively, and laboratory measurements of individual filtration rate (Clausen \& Riisgård 1996) with corrections for water temperature using a $\mathrm{Q}_{10}$ of 2.0. The clam population grazing potential was similarly estimated from population density, individual size and laboratory measurements of individual filtration rate (Riisgård \& Seerup 2003).

\section{Chl a}

During the campaign periods, water samples were taken daily at Stns 1, 2, 3 and 3a at sampling depths of $8,20,50,100$ and $200 \mathrm{~cm}$ above the bottom (max. depth at Stn 1 was $1.8 \mathrm{~m}$ ) using 'siphon mimics'. Siphon mimics consisted of black plastic tubing (inner diameter: $3 \mathrm{~mm}$ ) that at one end was mounted in bent aluminium tubes. The tubes were fastened 50, 100 and $200 \mathrm{~cm}$ above the bottom using metal rods and floats. At the other end, the plastic tubing was connected to a peristaltic pump. At the 2 lowermost depths, the aluminium tubes were fastened on $5 \times 5 \mathrm{~cm}$ PVC plates equipped with metal rods and inserted into the bottom, bringing the PVC plate level with the bottom. Water sampling was performed from an anchored boat using the peristaltic pump and pumping with a flow corresponding to the average filtration rate of the dominant suspension feeders (40 to $80 \mathrm{ml} \mathrm{min}^{-1}$ ). Of a $300 \mathrm{ml}$ water sample, $100 \mathrm{ml}$ was filtered on a glass-fibre carbon filter (GF/C), extracted in $96 \%$ ethanol overnight and analysed for chl a after correction for phaeopigments on a Turner fluorometer. In addition to point samples, depth-integrated water samples were taken regularly at Stns 3 and 5 during the campaign period. The realised grazing was estimated as the decline in chl a concentrations over time after breakdown of stratification during the campaign periods, based on the assumption that vertical processes are more important than horizontal processes in wind-driven, microtidal areas. 


\section{RESULTS}

\section{Physical forcing}

Wind speeds were on average $\sim 4 \mathrm{~m} \mathrm{~s}^{-1}$, and maximum wind speeds (averaged over $0.5 \mathrm{~h}$ ) ranged from 8 to $11 \mathrm{~m} \mathrm{~s}^{-1}$ in all of the campaigns. Current velocities, measured with electromagnetic current meters at $\mathrm{Stn} 3$, were generally low $\left(0.2\right.$ to $\left.3 \mathrm{~cm} \mathrm{~s}^{-1}\right)$ and mainly dominated by the tide. The turbulent fluctuations were assumed to be primarily reflected in the horizontal velocity components as $T_{U_{i X}} \times T_{U_{i Y}}$ since the z-component was considerably lower than the horizontal components (see below). The root-meansquare (rms) of each horizontal velocity component is equal to the standard deviation (SD) normalized by the mean and the turbulent fluctuations are therefore correlated with $\mathrm{SD}^{2}$. A step-wise regression analysis showed that wind speed was by far the most important parameter for turbulence generation in Kertinge Nor (Stn 3), followed by solar radiation (Table 1). Current speed was not important in the overall regression but was significant in 2 sampling periods.

The energy density spectra obtained from the ultrasonic current meter were in good agreement with the theoretical slope of $-5 / 3$ (Tennekes \& Lumley 1972). Turbulence was isotropic (i.e. of equal magnitude irrespective of direction) except at 10 and $20 \mathrm{~cm}$ heights, where the vertical component was marginally but consistently lower than the horizontal components. Neglecting this difference, the total turbulent kinetic energy $\left(E_{\text {kin }}\right)$ was calculated as follows:

Table 1. Summary of stepwise regression analysis of relations between turbulence $\left(\mathrm{SD}^{2}\right)$ and wind speed ${ }^{3}$, current speed ${ }^{2}$ and global solar radiation measured at Stn 3 in September 1995 and 1996 and July 1996. ns = not significant

\begin{tabular}{|c|c|c|c|c|}
\hline & Parameter & Factor & Weight & $\mathrm{p}$ \\
\hline $\begin{array}{l}\text { September } 95 \\
\left(\text { cumulative } r^{2}=0.54\right)\end{array}$ & $\begin{array}{c}\text { Wind }^{3} \\
\text { Current }^{2} \\
\text { Solar radiation } \\
\text { Intercept }\end{array}$ & $\begin{array}{c}0.00047 \\
0.00937 \\
- \\
-\end{array}$ & $\begin{array}{l}0.726 \\
0.151 \\
- \\
-\end{array}$ & $\begin{array}{c}<0.01 \\
<0.01 \\
\mathrm{~ns} \\
\mathrm{~ns}\end{array}$ \\
\hline $\begin{array}{l}\text { July } 96 \\
\left(\text { cumulative } r^{2}=0.57 \text { ) }\right.\end{array}$ & $\begin{array}{c}\text { Wind }^{3} \\
\text { Current }^{2} \\
\text { Solar radiation } \\
\text { Intercept }\end{array}$ & $\begin{array}{c}0.00032 \\
0.0194 \\
-0.000021 \\
-\end{array}$ & $\begin{array}{c}0.794 \\
0.098 \\
-0.114 \\
-\end{array}$ & $\begin{array}{c}<0.01 \\
<0.01 \\
<0.01 \\
\quad n s\end{array}$ \\
\hline $\begin{array}{l}\text { September } 96 \\
\left(\text { cumulative } r^{2}=0.58\right)\end{array}$ & $\begin{array}{c}\text { Wind }^{3} \\
\text { Current }^{2} \\
\text { Solar radiation } \\
\text { Intercept }\end{array}$ & \begin{tabular}{l}
\multicolumn{1}{c}{0.00041} \\
- \\
-0.000064 \\
-0.0083
\end{tabular} & $\begin{array}{c}0.837 \\
- \\
-0.206 \\
-\end{array}$ & $\begin{array}{c}<0.01 \\
\quad- \\
<0.01 \\
<0.05\end{array}$ \\
\hline $\begin{array}{l}\text { All data } \\
\text { (cumulative } r^{2}=0.53 \text { ) }\end{array}$ & $\begin{array}{c}\text { Wind }^{3} \\
\text { Current }^{2} \\
\text { Solar radiation } \\
\text { Intercept }\end{array}$ & \begin{tabular}{l}
\multicolumn{1}{c}{0.00034} \\
- \\
0.000027 \\
0.0048
\end{tabular} & $\begin{array}{c}0.784 \\
- \\
-0.119 \\
-\end{array}$ & $\begin{aligned} &< 0.01 \\
& \mathrm{~ns} \\
&<0.01 \\
&<0.01\end{aligned}$ \\
\hline
\end{tabular}

$$
E_{\text {kin }}=0.5 \times\left(\bar{u}^{12} \times \bar{v}^{\prime 2} \times \bar{w}^{\prime 2}\right)
$$

where $\bar{u}^{\prime}, \bar{v}^{\prime}$ and $\bar{w}^{\prime}$ are the fluctuations of the velocity components in the $x, y$ and $z$ directions, respectively. The ratio of turbulent kinetic energy at $100 \mathrm{~cm}$ versus $10 \mathrm{~cm}\left(E_{\text {kin100 }} / E_{\text {kin10 }}\right)$ above the bottom was highest for barren sand (2.7) and lowest for the vegetated stations (1.5 to 1.8), whereas the average log wave peaks were similar during the sampling events (Fig. 2). The turbulent dissipation rate $(\varepsilon)$ was calculated by integrating the power spectrum below the 'linear' (slope $=-5 / 3$ ) part of the spectrum until the Nyquist frequency (i.e. $15 \mathrm{~Hz}$ ):

$$
\varepsilon=2 \sum_{i=1}^{n} S\left(\omega_{i}\right) \Delta \omega
$$

where $\Delta \omega$ is the interval between the Fourier frequencies $\omega_{i}$ and $\omega_{i+1}$, and $n$ is the number of frequencies. The noise data were treated analogously and subtracted from $\varepsilon$. Generally, electronic noise was insignificant, except for a few occasions near the bottom on calm days when the noise was up to $28 \%$.

The calculated dissipation rates varied between $2 \times$ $10^{-7}$ and $5 \times 10^{-4} \mathrm{~m}^{2} \mathrm{~s}^{-3}$ and were lowest within eelgrass canopies during calm days and highest in surface water (i.e. $150 \mathrm{~cm}$ above bottom) during windy periods $\left(8.3 \mathrm{~m} \mathrm{~s}^{-1}\right)$. The dissipation rate scaled significantly to wind speed ${ }^{3}\left(r^{2}=0.51\right.$ to 0.56$)$ and the magnitude of the energy peak at the frequency of surface waves (10 to $20 \mathrm{~cm}: \mathrm{r}^{2}=0.58 ; 100 \mathrm{~cm}: \mathrm{r}^{2}=0.63$ ). Thus, most of the energy in the spectrum was contained in the waves rather than in the actual turbulence. The turbulent dissipation rate within the eelgrass bed $(10$ and $20 \mathrm{~cm}$ altitudes) was lower than above the bed but not lower than on nonvegetated (Stn 1) or sparsely vegetated (Stn 2) bottoms at similar heights.

The water column was stratified on $60 \%$ of the campaign days (excluding September 1996) and $70 \%$ of the time in the monitoring programme based on CTD profiles from Stn 3 from 1994 to 1996. Density differences and mixed layer depth were correlated to meteorological forcing functions, but only the depth of the upper mixed layer correlated to wind speeds (Table 2). The same set of correlations emerged when we used county data from 1994 to 1996 for mixed layer depth and density difference. Depth of the mixed layer could be modelled 


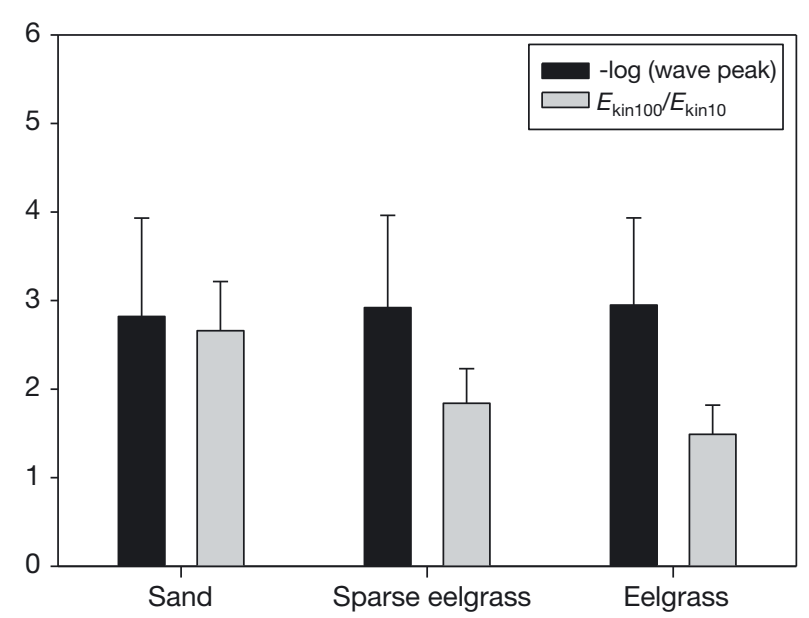

Fig. 2. Average ( $\pm 1 \mathrm{SD}$ ) log wave energy peak of the power spectrum and ratio of turbulent kinetic energy $\left(E_{\text {kin }}\right)$ at $100 \mathrm{~cm}$ versus 10 to $20 \mathrm{~cm}$ height above the bottom for sand (Stn 1), sparse eelgrass (Stn 2) and 100\% eelgrass cover (Stn 3)

as a function of wind speed for days with stratification (Fig. 3). Extrapolating the line to the depth at Stn $3(2.5$ to $3 \mathrm{~m})$ resulted in wind intensities of 4.5 to $5 \mathrm{~m} \mathrm{~s}^{-1}$ to create full mixing. During the campaign periods, wind speeds were $<4.5 \mathrm{~m} \mathrm{~s}^{-1}$ for 76 to $78 \%$ of the time, except in September 1996, where wind speeds were below $4.5 \mathrm{~m} \mathrm{~s}^{-1} 62 \%$ of the time. From the temperature loggers, it was found that stratification, defined as a difference in temperature between top and bottom of $>0.1^{\circ} \mathrm{C}$, occurred 50 to $75 \%$ of the time depending on the season.

There was a horizontal gradient in the density of the water column from the cove to the Great Belt. Within the cove, the mean density at Stn 1 was different from that of Stns 3 and 3a during all campaign periods. No correlation between horizontal density differences at the boundaries and vertical density difference at Stn 3 could be found ( $p>0.10)$.

Table 2. Correlation coefficients between wind speed ${ }^{3}$ averaged over the previous 12 or $24 \mathrm{~h}$, solar radiation average over the previous $24 \mathrm{~h}$, depth $(\mathrm{m})$ of the upper mixed layer and difference in $\sigma_{\mathrm{t}}$ at $\operatorname{Stn} 3 .{ }^{*} \mathrm{p}<0.05,{ }^{* *} \mathrm{p}<0.01$

\begin{tabular}{|lccccc|}
\hline & $\begin{array}{c}\text { Wind } \\
\text { speed } \\
12 \mathrm{~h}\end{array}$ & $\begin{array}{c}\text { Wind } \\
\text { speed }^{3} \\
24 \mathrm{~h}\end{array}$ & $\begin{array}{c}\text { Solar } \\
\text { radiation }\end{array}$ & $\begin{array}{c}\text { Mixed } \\
\text { layer } \\
\text { depth }\end{array}$ & $\Delta \sigma_{\mathrm{t}}$ \\
\hline Wind speed $^{3} 12 \mathrm{~h}$ & 1 & $0.832^{* *}$ & $-0.393^{*}$ & $0.524^{* *}$ & -0.198 \\
Wind speed $24 \mathrm{~h}$ & & 1 & $-0.365^{*}$ & $0.606^{* *}$ & -0.283 \\
Solar radiation & & & 1 & -0.209 & 0.279 \\
Mixed layer depth & & & & 1 & $\begin{array}{c}0.568^{* *} \\
1\end{array}$ \\
$\Delta \sigma_{\mathrm{t}}$ & & & & & \\
\hline
\end{tabular}

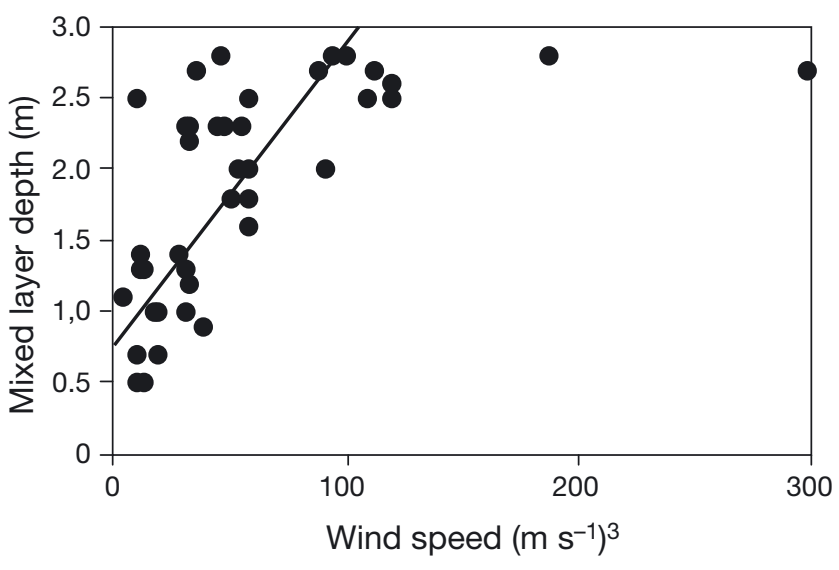

Fig. 3. Depth $(D, \mathrm{~m})$ of the upper mixed layer as a function of wind speed ${ }^{3}\left(\mathrm{WS}^{3},\left[\mathrm{~m} \mathrm{~s}^{-1}\right]^{3}\right)$ at Stn 3 using data from 5 campaign periods. The fitted line is a linear regression, $D=$ $0.016 \times \mathrm{WS}^{3}+1.04, \mathrm{r}^{2}=0.55$

\section{Benthic suspension feeders}

The distribution of the ascidian population of Ciona intestinalis in Kertinge Nor was limited to the central and northern part of the cove (Fig. 1), except in September 1996, where ascidians also were found in the southern parts of the cove. They were patchily distributed, with animals either solitary or in smaller or larger clumps attached mainly to the eelgrass, and densities varied between 0 and 1000 ind. $\mathrm{m}^{-2}$ within transects. The abundance and biomass of $C$. intestinalis also varied greatly between seasons, with the highest levels in late summer and early fall (Table 3, Fig. 4).

For the bivalves Mytilus edulis and Mya arenaria, a large recruitment of both species occurred in Kertinge Nor in 1993, but since then, the populations have been declining in abundance and increasing in individual size (Table 3, Fig. 4), indicating lack of additional recruitment (unpubl. data). Similarly to the ascidians, the blue mussel had a very patchy distribution, but blue mussels were found in all parts of Kertinge Nor. Clams were confined to the southern parts of the cove, except in the fall 1993 (Fig. 1).

While the grazing potential of Ciona intestinalis varied several fold between seasons, bivalve grazing was relatively stable (Table 3 ). The cumulated benthic grazing potential 
Table 3. Abundance, individual and population grazing rate and potential grazing pressure for the 3 main suspension feeders in Kertinge Nor from 1994 to 1996. Potential grazing pressure is shown as the fraction of the total volume of Kertinge Nor that is being filtered by the suspension feeders per day. For these calculations, a total area of $5.48 \mathrm{~km}^{2}$ and a mean depth of $2 \mathrm{~m}$ for Kertinge Nor were used. For calculation of population grazing rate, an area of $2.81 \mathrm{~km}^{2}$ is used for Ciona intestinalis, $3.81 \mathrm{~km}^{2}$ for Mytilus edulis and $2.0 \mathrm{~km}^{2}$ for Mya arenaria

\begin{tabular}{|c|c|c|c|c|c|c|c|c|c|c|c|c|c|}
\hline \multirow[t]{2}{*}{ Time } & \multicolumn{3}{|c|}{$\begin{array}{l}\text { Abundance } \\
\text { (ind. } \mathrm{m}^{-2} \text { ) }\end{array}$} & \multicolumn{3}{|c|}{$\begin{array}{l}\text { Individual grazing rate } \\
\qquad\left(\mathrm{ml} \mathrm{min}^{-1}\right)\end{array}$} & \multicolumn{3}{|c|}{$\begin{array}{l}\text { Population grazing } \\
\text { rate }\left(\times 10^{4} \mathrm{~m}^{3} \mathrm{~h}^{-1}\right)\end{array}$} & \multicolumn{3}{|c|}{$\begin{array}{l}\text { Potential grazing } \\
\text { pressure }\left(\mathrm{Q} \mathrm{d}^{-1}\right)\end{array}$} & \multirow[t]{2}{*}{ Total } \\
\hline & Ciona & Mytilus & Муа & Ciona & Mytilus & Муа & Ciona & Mytilus & муа & Ciona & Mytilus & Муа & \\
\hline May 94 & 169 & 211 & 635 & 12.9 & 2.0 & 2.1 & 37 & 10 & 16 & 0.8 & 0.2 & 0.3 & 1.3 \\
\hline Oct 94 & 168 & 122 & 392 & 11.1 & 5.0 & 3.8 & 31 & 14 & 18 & 0.7 & 0.3 & 0.4 & 1.4 \\
\hline Jun 95 & 152 & 145 & 313 & 46.6 & 11.4 & 6.2 & 120 & 38 & 23 & 2.6 & 0.8 & 0.5 & 3.9 \\
\hline Sep 95 & 36 & 129 & 71 & 16.2 & 22.3 & 9.9 & 10 & 66 & 8 & 0.2 & 1.4 & 0.2 & 1.8 \\
\hline Apr 96 & 69 & 71 & 173 & 12.4 & 19.9 & 7.4 & 14 & 32 & 15 & 0.3 & 0.7 & 0.3 & 1.3 \\
\hline Jul 96 & 448 & 66 & 173 & 14.2 & 38.5 & 12.8 & 107 & 58 & 27 & 2.4 & 1.3 & 0.6 & 4.3 \\
\hline Sep 96 & 579 & 66 & 125 & 27.3 & 33.5 & 14.2 & 267 & 51 & 21 & 5.8 & 1.1 & 0.5 & 7.4 \\
\hline
\end{tabular}
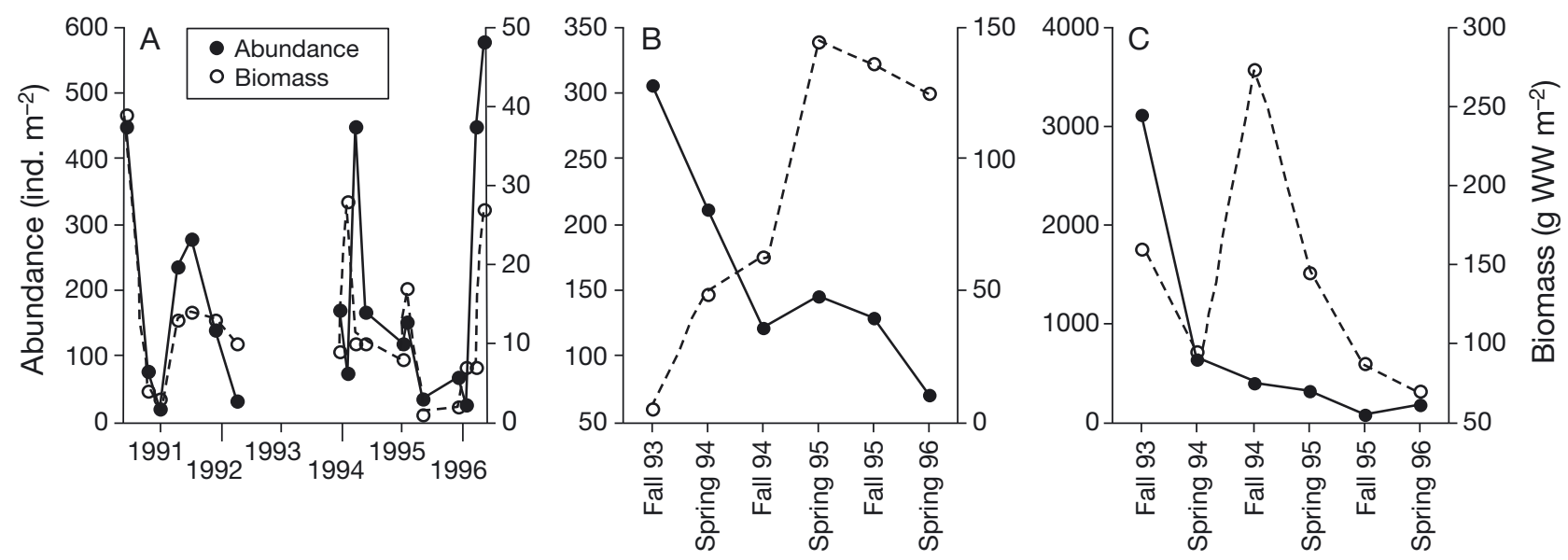

Fig. 4. Abundance (ind. $\mathrm{m}^{-2}$ ) and biomass $\left(\mathrm{g} \mathrm{m}^{-2}\right.$ ) of (A) Ciona intestinalis, (B) Mytilus edulis and (C) Mya arenaria in Kertinge Nor. Data on C. intestinalis from 1991 to 1992 from Petersen \& Riisgård (1992)

was more than the entire water volume of the cove per day during all campaign periods.

Realisation of the grazing potential was estimated for Ciona intestinalis (Table 4), the dominant suspension feeder in the system. The realised grazing was 40 to $91 \%$, with an average $( \pm \mathrm{SD})$ of $64 \% \pm 21 \%$ when based on CI using data from all campaign periods. The measured in situ growth in September 1996 (Table 4) differed among stations, with significantly (Mann Whitney test, $\mathrm{p}=0.0104$ ) higher average in situ growth rate for all heights at Stn $3\left(4.3 \% \mathrm{~d}^{-1}\right)$ compared to Stn $2\left(3.2 \% \mathrm{~d}^{-1}\right)$ but with no significant difference between heights. Realised grazing based on in situ growth rates varied between 20 and $56 \%$, with an average $( \pm 1 \mathrm{SD})$ of $36 \% \pm 16 \%$ (Table 4$)$. The average $( \pm 1 \mathrm{SD})$ realised grazing using both methods was $48 \pm 23 \%$.

\section{Chl a}

Depth-integrated samples taken at Stns 3 and 5 during the campaign periods showed (Table 5) generally lower levels of chl a in Kertinge Nor (Stn 3) than in Kerteminde Fjord (Stn 5). The same overall pattern emerged from the county monitoring programme from 1994 to 1996.

Typical profiles sampled with siphon mimics of chl a versus height above the bottom are shown in Fig. 5, showing a loss of chl a toward the bottom. Point samples of chl a were analysed statistically using ANOVA followed by Tukey post-hoc tests (0.05 level). Prior to analysis, the data sets were checked to see if they met the assumptions of normal distribution and homogeneity of variance required to apply ANOVA. Appropriate data trans- 
Table 4. Estimated condition index (CI) and CI-derived growth rates, in situ growth rates for Ciona intestinalisat different heights from the bottom in September 1996 at Stns 2 and 3, chl a concentrations, grazing rates and potential grazing rates (calculated as described by Petersen \& Riisgård 1992). The realised grazing of C. intestinalis was estimated from CI-derived growth rates, in situ growth rates and decreasing chl a concentrations after breakdown of stratification (see Fig. 8). In April 1996, chl a concentrations increased after the breakdown, and the realised grazing could not be estimated

\begin{tabular}{|c|c|c|c|c|c|c|c|c|}
\hline & $\begin{array}{l}\text { Height } \\
\quad(\mathrm{cm})\end{array}$ & $\mathrm{CI}$ & $\begin{array}{l}\text { Growth } \\
\text { rate } \\
\left(\% d^{-1}\right)\end{array}$ & $\begin{array}{c}\text { Chl a } \\
\left(\mu g l^{-1}\right)\end{array}$ & 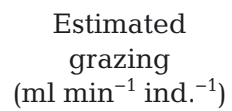 & $\begin{array}{c}\text { Potential } \\
\text { grazing } \\
\left(\mathrm{ml} \mathrm{\text {min } ^ { - 1 } \text { ind. }}{ }^{-1}\right)\end{array}$ & $\begin{array}{c}\text { Realised } \\
\text { grazing } \\
\text { (growth, \%) }\end{array}$ & $\begin{array}{r}\text { Realised } \\
\text { grazing } \\
\text { (chl a, \% }\end{array}$ \\
\hline \multicolumn{9}{|c|}{ In situ CI } \\
\hline Jun 95 & & 0.67 & 7.42 & 1.8 & 36.0 & 46.5 & 77 & 68 \\
\hline Sep 95 & & 0.61 & 5.42 & 1.4 & 7.3 & 16.3 & 45 & 38,40 \\
\hline Apr 96 & & 0.58 & 4.42 & 1.6 & 11.3 & 12.4 & 91 & - \\
\hline Jul 96 & & 0.65 & 6.83 & 1.2 & 5.7 & 14.2 & 40 & 66 \\
\hline Sep 96 & & 0.63 & 6.18 & 1.3 & 17.7 & 27.3 & 65 & 61 \\
\hline \multicolumn{9}{|c|}{ In situ growth } \\
\hline \multirow[t]{3}{*}{ Stn 2} & 20 & & 2.48 & 1.4 & 6.9 & 22.3 & 31 & \\
\hline & 50 & & 2.72 & 2.4 & 4.6 & 22.6 & 20 & \\
\hline & 100 & & 3.85 & 3.4 & 5.3 & 24.1 & 22 & \\
\hline \multirow[t]{3}{*}{ Stn 3} & 20 & & 4.20 & 1.5 & 13.8 & 24.6 & 56 & \\
\hline & 50 & & 4.10 & 1.7 & 11.6 & 24.3 & 48 & \\
\hline & 100 & & 4.68 & 3.0 & 8.4 & 25.5 & 33 & \\
\hline
\end{tabular}
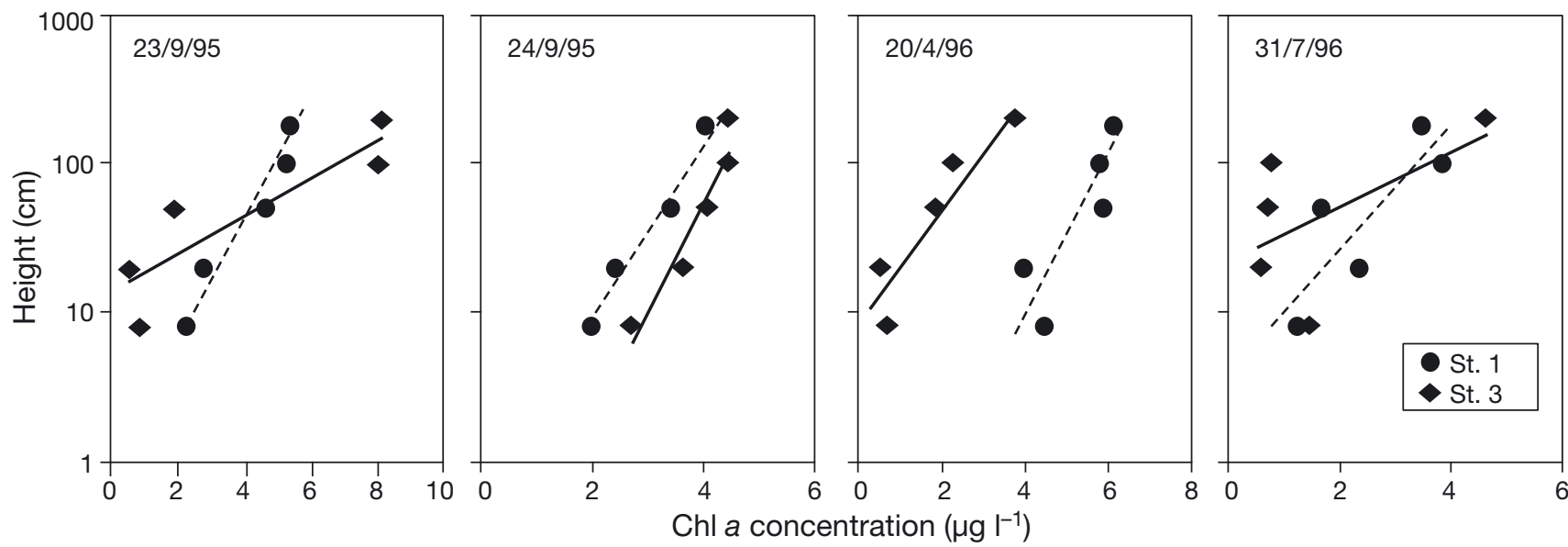

Fig. 5. Concentrations of chl a at Stns 1 and 3, sampled 8, 20, 50, 100 and $200 \mathrm{~cm}$ (180 cm at Stn 1) above the bottom, sampled using siphon mimics. Samples were taken on 2 consecutive days in September 1995 (with [23 September] and without [24 September] stratification), 1 day in April 1996 and 1 day in July 1996. Fitted lines represent linear regression between ln(depth) and concentration of chl $a_{\text {; }}$ the $\mathrm{r}^{2}$ for the lines are: 23 September, Stn 1: 0.93, Stn 3: 0.78; 24 September Stn 1: 0.97,

Stn 3: 0.92; 20 April Stn 1: 0.72, Stn 3: 0.86; and 31 July Stn 1: 0.69, Stn 3: 0.45

Table 5. Concentrations of chl $a$ in depth-integrated samples collected at Stns 3 and 5 (see Fig. 1) in Kertinge Nor during campaign periods. $\mathrm{ns}=$ not significant

\begin{tabular}{|lccc|}
\hline Period & Stn $5\left(\mathrm{mg} \mathrm{m}^{-3}\right)$ & Stn $3\left(\mathrm{mg} \mathrm{m}^{-3}\right)$ & $\mathrm{p}$ \\
\hline Jun 95 & $2.60 \pm 0.17$ & $1.53 \pm 0.38$ & $<0.01$ \\
Sep 95 & $4.33 \pm 1.45$ & $4.10 \pm 1.51$ & $\mathrm{~ns}$ \\
Apr 96 & $2.58 \pm 0.34$ & $2.60 \pm 0.39$ & $\mathrm{~ns}$ \\
Jul 96 & $4.60 \pm 1.09$ & $2.55 \pm 1.27$ & $<0.05$ \\
Sep 96 & $7.25 \pm 1.97$ & $1.63 \pm 0.88$ & $<0.01$ \\
\hline
\end{tabular}

formations were applied to adjust the data to meet these assumptions. In all sampling periods, concentrations of chl a were significantly different among heights, with the lowest concentrations just above the bottom (Table 6). There were, however, differences among stations and sampling periods. In general, at stations with no ascidians or in seasons (June and April) during which old ascidians lie on the bottom, concentrations of chl a were significantly lower only in the 1 or 2 lowest heights above the bottom compared to the upper part of the water 
Table 6. Summary of statistical analyses (ANOVA and Tukey post-hoc test) of chl a concentrations (dependent variable) sampled using siphon mimics as a function of height above the bottom $(8,20,50,100$ and $200 \mathrm{~cm})$ in different sampling periods. Tukey post-hoc tests were used to indicate differences between the individual heights. $\mathrm{ns}=$ not significant

\begin{tabular}{|c|c|c|c|}
\hline Time & Station & $\mathrm{p}$ & Comparison \\
\hline \multirow[t]{5}{*}{ Jun 95} & All & 0.0493 & $8<20,50,100,200$ \\
\hline & 1 & ns & - \\
\hline & 2 & ns & - \\
\hline & 3 & ns & - \\
\hline & 3a & ns & - \\
\hline \multirow[t]{5}{*}{ Sep 95} & All & $<0.0001$ & $8,20<50<100,200$ \\
\hline & 1 & 0.0227 & $8,20<100$ \\
\hline & 2 & 0.0653 & $8,20<100,200$ \\
\hline & 3 & 0.0001 & $8,20,50<100,200$ \\
\hline & 3a & 0.1344 & $20<100,200$ \\
\hline \multirow[t]{5}{*}{ Apr 96} & All & $<0.0001$ & $8,20<50,100,200$ \\
\hline & 1 & 0.0158 & $8<50,100$ \\
\hline & 2 & ns & - \\
\hline & 3 & $<0.0001$ & $8,20<50,100,200$ \\
\hline & 3a & 0.1009 & $8<50,100,200$ \\
\hline \multirow[t]{5}{*}{ Jul 96} & All & $<0.0001$ & $8,20,50<100<200$ \\
\hline & 1 & 0.0209 & $8,50<100$ \\
\hline & 2 & 0.0033 & $8,20,50,100<200$ \\
\hline & 3 & 0.0019 & $8,20,50,100<200$ \\
\hline & 3a & 0.0007 & $8,20<50,100,200$ \\
\hline \multirow[t]{5}{*}{ Sep 96} & & 0.0431 & $8,20,50<200$ \\
\hline & & ns & - \\
\hline & & ns & - \\
\hline & & 0.0042 & $20,50,100<200$ \\
\hline & & 0.1014 & $8,20<200$ \\
\hline
\end{tabular}

column (Table 6). In seasons (July and September) during which the ascidians were attached to eelgrass leaves in the water column or where a very large population of ascidians was present, the chl $a$ concentrations were significantly lower up to $100 \mathrm{~cm}$ above the bottom.

The depletion rate of chl a was estimated as the slope of the vertical gradient above the bottom, with ln-transformed height as the independent variable and concentration of chl $a$ as the dependent variable. A high value of the slope indicates a large difference in concentrations between the top and bottom and, thus, depletion. A total of 139 profiles were analysed. The depletion rate varied among stations, seasons and days for each station. For all stations, the mean chl a depletion rate was significantly (ANOVA, $\mathrm{p}<$ 0.01 ) higher in a stratified water column than a mixed water column. The depletion rate was correlated to the duration of stratified/mixed periods, as determined from the temperature loggers (Fig. 6), but even under well-mixed conditions, depletion could

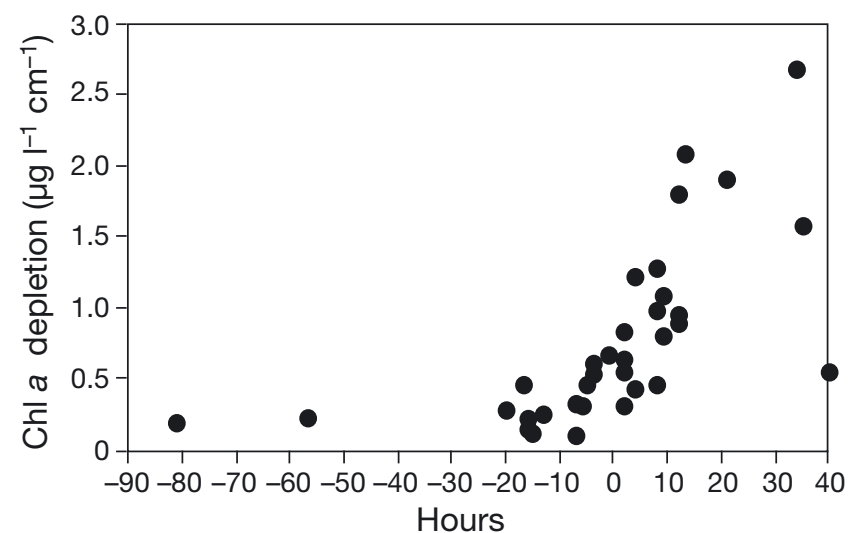

Fig. 6. Chl a depletion rate (slope of the linear relation between $\ln$ [depth] and concentration of chl a) at Stn 3 as a function of hours of mixed conditions before sampling in September 1995. Negative $x$-values indicate time with mixed conditions, and positive $x$-values indicate time with stratified conditions prior to sampling

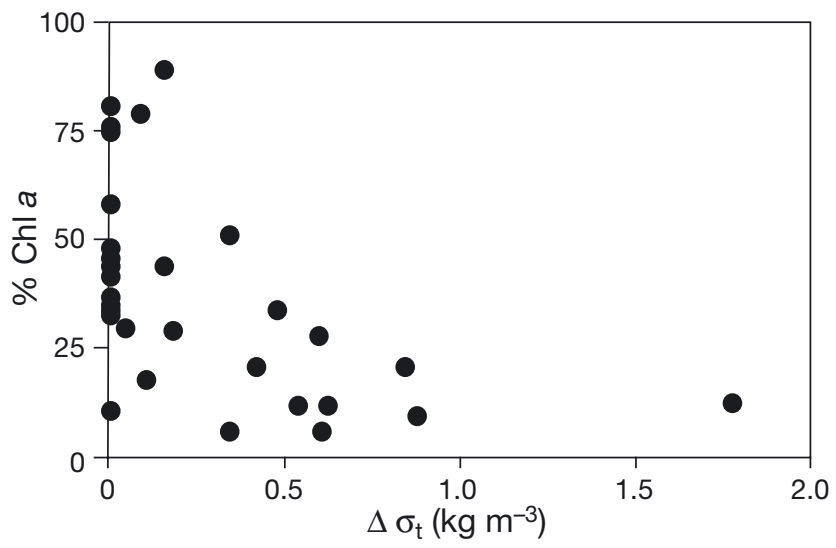

Fig. 7. Percentage concentration of chl $a$ at $20 \mathrm{~cm}$ compared to $200 \mathrm{~cm}$ above the bottom at Stn 3 as a function of difference in density of the water $\left(\Delta \sigma_{\mathrm{t}}, \mathrm{kg} \mathrm{m}^{-3}\right)$ between 20 and $200 \mathrm{~cm}$ above the bottom

be detected (Figs. $6 \&$ 7). Interestingly, depletion rates decreased after 30 to $40 \mathrm{~h}$ of stratification, possibly indicating nutrient limitation of phytoplankton growth in the surface layer (Fig. 6).

During stratified conditions (high $\Delta \sigma_{t}$ ), the suspension feeders were not in contact with the upper part of the water column, and chl a could build up above the pycnocline (Fig. 8). When stratification broke down, area-specific or upper-layer concentrations of $\mathrm{chl}$ a decreased. The reduction in area-specific chl $a$ from before and after the breakdown of stratification was 38 to $68 \%$, with an average ( \pm 1 SD) of $55 \pm 15 \%$ during all campaign periods, except for April 1996, when concentration increased. 


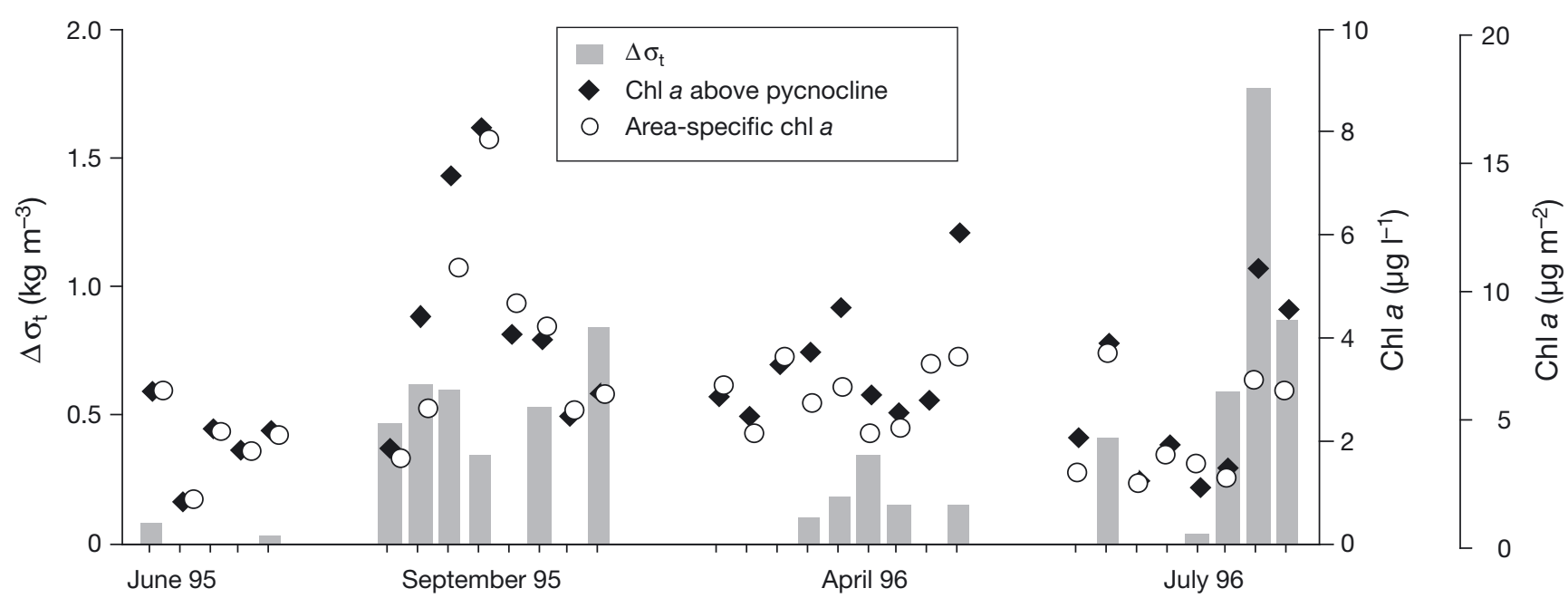

Fig. 8. Concentration of chl a $\left(\mu \mathrm{g} \mathrm{l}^{-1}\right)$ above the pycnocline, depth-integrated area-specific chl a concentrations and density difference of the water between top and bottom $\left(\Delta \sigma_{\mathrm{t}}, \mathrm{kg} \mathrm{m}^{-3}\right)$ at $\operatorname{Stn} 3$. The $x$-axis scale shows measurement days in each field campaign

\section{DISCUSSION}

Kertinge Nor is a typical Danish estuary characterised as shallow, highly eutrophic and densely populated by benthic suspension feeders (Conley et al. 2000). Accordingly, the daily grazing potential of the benthic suspension feeder populations in Kertinge Nor was greater than the total water column of the cove from 1995 to 1996. Despite the high grazing potential, phytoplankton was present in the water column in all campaign periods, indicating that the grazing potential was not fully exploited. This pattern was supported by estimates of the 'realised' grazing using different approaches. From measurements of suspension feeder parameters, the realised grazing was estimated to be 20 to $90 \%$, with an average of $48 \% \pm 23 \%$. From the decline in area-specific chl a concentrations after breakdown of stratification, the realised grazing was $\sim 38$ to $68 \%$, with an average of $55 \% \pm 15 \%$. In one occasion, chl a concentrations increased after breakdown of stratification. This event was ignored in the analysis and was probably caused by increased growth of phytoplankton due to renewal of nutrients to the surface layer or strong advection. Thus, there was a high variability in the realised grazing estimates, but average values were similar.

The recorded in situ growth rates were lower closer to the bottom than at $100 \mathrm{~cm}$ above the bottom and comparable to previous estimates taking concentrations of chl $a$ into account (Petersen et al. 1997). However, in situ growth rates were lower than CI-derived growth rates in September 1996. CI is an indirect measure of growth but may reflect the actual growth of the ascidians better because it is measured from animals in their natural habitat over a longer time scale. For in situ growth, the slower growth at Stn 2 than at Stn 3 is surprising in view of the similar concentrations of chl a. This could indicate that other food sources than phytoplankton, such as zooplankton and detritus aggregates, were available in the eelgrass bed (Judge et al. 1993, Nielsen \& Maar 2007). Thus, the realised grazing estimated from growth rates will be even lower if part of the ascidian growth is derived from food sources other than phytoplankton. In situ growth and CI integrate feeding conditions over a longer time span and will thus not reflect instantaneous responses in growth to, e.g., breakdown of stratification. An immediate response could have been obtained with RNA/DNA ratios (Wildish et al. 2008). By using integrated measures for growth, however, we obtained ecologically relevant data for the impact of continuously on-going stratification/destratification on growth and thus food availability.

From water column parameters, there was clear evidence of $\mathrm{chl}$ a depletion toward the bottom in areas with a benthic grazing pressure, as observed in other studies (Møhlenberg 1995, Riisgård et al. 1996b, Nielsen \& Maar 2007, Dolmer 2000a). The seasonal and geographical variation in realised grazing was reflected in differences in mean concentrations of chl $a$ and depletion rates among stations and seasons. On several occasions, concentrations of $\mathrm{chl} a$ were $<0.7 \mathrm{mg} \mathrm{m}^{-3}$ and thus at a level where large reductions in filtration rate have been recorded for 
several suspension feeders (Petersen \& Riisgård 1992, Riisgård et al. 2003). Especially at stations in the central part of the cove and in September 1996, concentrations in the lower layers were frequently between 0.3 and $0.7 \mathrm{mg} \mathrm{m}^{-3}$, and comparisons of depletion rates between seasons are therefore not straightforward.

Mixing of the water column was the main factor determining realised grazing on the phytoplankton community in Kertinge Nor. This could be seen in the depletion rates and area-specific chl a concentrations in relation to stratification/mixing (Figs. 6, 7 \& 8). In the Roskilde Fjord and Limfjorden, 2 other shallow, micro-tidal estuaries with a huge benthic grazing potential, mixing of the water column similarly determined the development of phytoplankton biomass (Møhlenberg 1995) and filtration rates of plankton over mussel beds (Maar et al. 2007). However, we have here demonstrated that depletion rate was directly correlated to time elapsed from stratification/destratification and further that, even during mixed conditions, depletion rates were variable. This indicates that the intensity of mixing determines the fate of phytoplankton and the supply of food to the benthic suspension feeders, as it does in macro-tidal areas with moderate to high current velocities (Wildish \& Kristmanson 1984, Frechette \& Bourget 1985, Butman 1987, Frechette et al. 1989, Wildish \& Kristmanson 1997). Breakdown of stratification may, however, also bring nutrients into the water column, counteracting the grazing pressure (Møhlenberg 1995) and thereby potentially affecting estimates of realised filtration. Likewise, persistent stratification may lead to nutrient depletion in the upper part of the water column, which can be reflected in reduced depletion rates, as seen in Kertinge Nor.

During the campaign periods, wind-generated surface waves were the main external energy source in Kertinge Nor and thus the main parameter responsible for generating mixing. Similarly, solar radiation was the main parameter for generating stratification. Density-driven transport of water from the Great Belt may also lead to stratification (Riisgård 1998, Riisgård et al. 1998), but the importance of this mechanism on a larger temporal scale is not obvious from our study. To illustrate the importance of wind and solar radiation, we applied a simple 1D model for stratification, described by Møhlenberg (1999). The model correctly predicted the presence/absence of stratification on $80 \%$ of the campaign days. In all of the wrong predictions, the model predicted stratification where no stratification was found. If density- driven currents had caused stratification, then the discrepancy between the model results and measured densities should have been the reverse, i.e. a prediction of a mixed column where actual measurements showed stratification. If we extend the analyses to include data from the county monitoring programme, a similar trend emerges. From 1994 to 1996, the county had 114 sampling days with CTD casts. The model predictions for this data set were $77 \%$ correct. In $13 \%$ of the sampling occasions, the model predicted a mixed water column when stratification was observed, and in $10 \%$, the model predicted stratification when no stratification was found. This indicates that although density-driven currents may occasionally be very important for the benthic suspension feeders and realisation of their grazing potential, the main drivers in the cove for the contact between grazers and the water column is windgenerated waves and solar radiation. In $\sim 60$ to $70 \%$ of the time, for both the campaign periods and the monitoring data, the water column was stratified according to the CTD profiles. Data from the continuous temperature logger showed that stratification occurred up to 50 to $75 \%$ of the time. Thus, the periods with complete mixing of the water column accounted for $\sim 25$ to $50 \%$ of the time, when the grazing potential could be fully realised.

In addition to the magnitude of the grazing potential, the position of the grazers in the water column, i.e. whether they are infaunal, epibenthic or epiphytic, will affect the planktonic community. In the present study, the critical height of the depleted layer shifted in accordance with the position of the major grazer in the water column. A difference in position of the depleted layer under similar hydrographical conditions has to our knowledge not been shown before, possibly because ascidians or other epiphytic animals rarely have been studied in this context. Ascidians will benefit from being attached to eelgrass leaves off the bottom but will thereby increase the grazing pressure on the phytoplankton. The depleted benthic boundary layer that normally builds up above dense assemblages of benthic suspension feeders (e.g. Wildish \& Kristmanson 1997) may thus be additionally depleted by epibenthic suspension feeding. Further, in Kertinge Nor, turbulence generated by roughness elements, like mussels (van Duren et al. 2006), is too low to create mixing due to the low current-velocity regime (Wiles et al. 2006), and current-induced mixing outside the eelgrass beds is limited during stratified periods. Under these conditions, bio-mixing generated by the suspension feeders themselves may be important for 
mixing processes and the transport of food to clams and mussels (Larsen \& Riisgård 1997).

Dissipation rates in the present study were lower inside the eelgrass bed than outside or above the canopy. This implies that suspension feeders within the eelgrass bed have access to the water column above the bed (depending on stratification). Additionally, turbulent kinetic energy showed a steeper gradient $\left(E_{\text {kin100 }} / E_{\text {kin10 }}\right)$ above barren sand compared to vegetated stations because the bed at moderate energy input acts like a buffer for wave action (Ward et al. 1984, Worcester 1995). It is generally accepted that currents are deflected by seagrass beds, leading to decreased flow within the canopy and increased flow and turbulence levels above the canopy (Gambi et al. 1990, Ackerman \& Okubo 1993, Abdelrhman 2003). An expected increase in turbulent intensity as a response to reduction in current velocity within beds (Gambi et al. 1990) could not be found, which is in agreement with observations in another lowcurrent environment (Worcester 1995). The dampening of the energy input from the surroundings within the bed will reduce resuspension (Terrados \& Duarte 2000) and any benefit within the bed for suspension feeders will then be due to the ability of seagrass beds to trap particles (Gacia et al. 1999) originating both within and outside of the bed (Judge et al. 1993, Duarte et al. 1999).

In summary, benthic grazing on phytoplankton communities can be of major importance in shallow coastal habitats. The realisation of the grazing potential will depend primarily on physical forcing and to a lesser extent on where the grazers are positioned in or above the bottom. In micro-tidal areas, windgenerated waves and solar radiation constitute the main physical drivers determining the mixing of the water column. Suspension feeders attached to eelgrass and thus positioned above the bottom have an advantage compared to suspension feeders on or in the bottom. Estimates of realised grazing potentials based on in situ growth, CI and chl a concentrations were highly variable but on average were $50 \%$ of the potential capacity. This was somewhat higher than during the 25 to $50 \%$ of the time when the water column was fully mixed.

Acknowledgements. We thank H. Riisgård for kind assistance and hospitality during the field campaigns and A. van Acker for improving the style of the manuscript. This research was funded by the ELOISE programme of the European Commission (project 'Physical forcing and biogeochemical fluxes in shallow coastal ecosystems', contract MAS3-CT96-0053) and the Danish Environmental Protection Agency.

\section{LITERATURE CITED}

Abdelrhman MA (2003) Effect of eelgrass Zostera marina canopies on flow and transport. Mar Ecol Prog Ser 248: $67-83$

Ackerman JD, Okubo A (1993) Reduced mixing in a marine macrophyte canopy. Funct Ecol 7:305-309

Agger CT, Kaas H, Knipschildt F, Brodersen $\mathrm{K}$ and others (1994) Marine områder - Fjorde, kyster og åbent hav. Vandmiljøplanens Overvågningsprogram 1993. Report No. 117, Danmarks Miljøundersøgelser

Asmus H, Asmus RM, Prins TC, Dankers N, Frances G, Maass B, Reise K (1992) Benthic-pelagic flux rates on mussel beds: tunnel and tidal flume methodology compared. Helgol Meersunters 46:341-361

Butman CA (1987) Larval settlement of soft-sediment invertebrates: the spatial scales of pattern explained by active habitat selection and the emerging rôle of hydrodynamical processes. Oceanogr Mar Biol Annu Rev 25: 115-165

Butman CA, Fréchette M, Geyer WR, Starczak VR (1994) Flume experiments on food supply to the blue mussel Mytilus edulis L. as a function of boundary-layer flow. Limnol Oceanogr 39:1755-1768

$>$ Caraco NF, Cole JJ, Raymond PA, Strayer DL, Pace ML, Findlay SEG, Fischer DT (1997) Zebra mussel invasion in a large, turbid river: phytoplankton response to increased grazing. Ecology 78:588-602

Clausen I, Riisgård HU (1996) Growth, filtration and respiration in the mussel Mytilus edulis: no evidence for physiological regulation of the filter-pump to nutritional needs. Mar Ecol Prog Ser 141:37-45

> Cloern JE (1982) Does the benthos control phytoplankton biomass in South San Francisco Bay? Mar Ecol Prog Ser 9:191-202

Conley DJ, Kaas H, Møhlenberg F, Rasmussen B, Windolf J (2000) Characteristics of Danish estuaries. Estuaries 23: 820-837

Dolmer P (2000a) Algal concentration profiles above mussel beds. J Sea Res 43:113-119

> Dolmer P (2000b) Feeding activity of mussels Mytilus edulis related to near-bed currents and phytoplankton biomass. J Sea Res 44:221-231

Duarte CM, Benavent E, Sánchez Md C (1999) The microcosm of particles within seagrass Posidonia oceanica canopies. Mar Ecol Prog Ser 181:289-295

Frechette M, Bourget E (1985) Energy flow between the pelagic and benthic zones: factors controlling particulate organic matter available to an intertidal mussel (Mytilus edulis) bed. Can J Fish Aquat Sci 42:1158-1165

> Frechette M, Butman CA, Geyer WR (1989) The importance of boundary-layer flows in supplying phytoplankton to the benthic suspension feeder, Mytilus edulis L. Limnol Oceanogr 34:19-36

> Gacia E, Granata TC, Duarte CM (1999) An approach to measurement of particle flux and sediment retention within seagrass (Posidonia oceanica) meadows. Aquat Bot 65:255-268

Gambi MC, Nowell ARM, Jumars PA (1990) Flume observations on flow dynamics in Zostera marina (eelgrass) beds. Mar Ecol Prog Ser 61:159-169

Gytre T (1976) The use of a high sensitivity ultrasonic current meter in an oceanographic data acquisition system. Radio Electr Eng 46:617-623

> Hily C (1991) Is the activity of benthic suspension feeders a 
factor controlling water quality in the Bay of Brest? Mar Ecol Prog Ser 69:179-188

> Judge ML, Coen L.D., Heck KL Jr (1993) Does Mercenaria mercenaria encounter elevated food levels in seagrass beds? Results from a novel technique to collect suspended food resources. Mar Ecol Prog Ser 92:141-150

$>$ Jürgensen C (1995) Modelling of nutrient release from the sediment in a tidal inlet, Kertinge Nor, Funen, Denmark. Ophelia 42:163-178

Larsen PS, Riisgård HU (1997) Biomixing generated by benthic filter feeders: a diffusion model for near-bottom phytoplankton depletion. J Sea Res 37:81-90

Lemmens JWTJ, Clapin G, Lavery P, Cary J (1996) Filtering capacity of seagrass meadows and other habitats of Cockburn Sound, Western Australia. Mar Ecol Prog Ser 143:187-200

> Loo LO, Rosenberg R (1989) Bivalve suspension-feeding dynamics and benthic-pelagic coupling in an eutrophicated marine bay. J Exp Mar Biol Ecol 130:253-276

> Maar M, Nielsen TG, Bolding K, Burchard H, Visser AW (2007) Grazing effects of blue mussel Mytilus edulis on the pelagic food web under different turbulence conditions. Mar Ecol Prog Ser 339:199-213

Møhlenberg F (1995) Regulating mechanisms of phytoplankton growth and biomass in a shallow estuary. Ophelia 42:239-256

Møhlenberg F (1999) Effect of meteorology and nutrient load on oxygen depletion in a Danish micro-tidal estuary. Aquat Ecol 33:55-64

Møhlenberg F, Jürgensen C (eds) (1994) Spatial and temporal variation in phosphorus in a small marine inlet after cut off of sewer discharges. Olsen \& Olsen, Fredensborg

> Monismith SG, Koseff JR, Thompson JK, O'Riordan CA, Nepf HM (1990) A study of model bivalve siphonal currents. Limnol Oceanogr 35:680-696

Nielsen TG, Maar M (2007) Effects of a blue mussel Mytilus edulis bed on vertical distribution and composition of the pelagic food web. Mar Ecol Prog Ser 339:185-198

Petersen JK (2004) Grazing on pelagic primary producers the role of benthic suspension feeders in estuaries. In: Nielsen SL, Banta GT, Pedersen MF (eds) Estuarine nutrient cycling: the influence of primary producers. Kluwer Academic Publishers, Dordrecht, p 129-152

Petersen JK, Riisgård HU (1992) Filtration capacity of the ascidian Ciona intestinalis and its grazing impact in a shallow fjord. Mar Ecol Prog Ser 88:9-17

Petersen JK, Schou O, Thor P (1995) Growth and energetics of the ascidian Ciona intestinalis (L.). Mar Ecol Prog Ser 120:175-184

Petersen JK, Schou O, Thor P (1997) In situ growth of the ascidian Ciona intestinalis (L.) and the blue mussel Mytilus edulis in an eelgrass meadow. J Exp Mar Biol Ecol 218:1-11

Riisgård HU, Seerup DF (2003) Filtration rates in soft clam,

Editorial responsibility: Hans-Heinrich Janssen, Oldendorf/Luhe, Germany
Mya arenaria: effects of temperature and body size. Sarsia 88:425-428

- Riisgård HU, Kittner C, Seerup DF (2003) Regulation of opening state and filtration rate in filter-feeding bivalves (Cardium edule, Mytilus edulis, Mya arenaria) in response to low algal concentration. J Exp Mar Biol Ecol 284:105-127

> Riisgaard HU, Seerup DF, Jensen MH, Glob E, Larsen PS (2004) Grazing impact of filter-feeding zoobenthos in a Danish fjord. J Exp Mar Biol Ecol 307:261-271

> Riisgård HU (1998) Filter feeding and plankton dynamics in a Danish fjord: a review of the importance of flow, mixing and density-driven circulation. J Environ Manag 53: 195-207

Riisgård HU, Jürgensen C, Clausen T (1996a) Filter-feeding ascidians (Ciona intestinalis) in a shallow cove: implications of hydrodynamics for grazing impact. J Sea Res 35: 293-300

> Riisgård HU, Poulsen L, Larsen PS (1996b) Phytoplankton reduction in near-bottom water caused by filter-feeding Nereis diversicolor-implications for worm growth and population grazing impact. Mar Ecol Prog Ser 141:47-54

> Riisgård HU, Jensen AS, Jürgensen C (1998) Hydrography, near-bottom currents and grazing impact of the benthic filter-feeding ascidian Ciona intestinalis in a Danish fjord. Ophelia 49:1-16

> Roditi HA, Caraco NF, Cole JJ, Strayer DL (1996) Filtration of Hudson River water by the zebra mussel (Dreissena polymorpha). Estuaries 19:824-832

Tennekes H, Lumley JL (1972) A first course in turbulence. The MIT Press, Cambridge, MA

Terrados J, Duarte CM (2000) Experimental evidence of reduced particle resuspension within a seagrass (Posidonia oceanica L.) meadow. J Exp Mar Biol Ecol 243:45-53

van Duren LA, Herman PMJ, Sandee AJJ, Heip CHR (2006) Effects of mussel filtering activity on boundary layer structure. J Sea Res 55:3-14

Ward LG, Kemp M, Boynton WR (1984) The influence of waves and seagrass communities on suspended particulates in an estuarine embayment. Mar Geol 59:85-103

> Wildish DJ, Kristmanson DD (1984) Importance to mussels of a benthic boundary layer. Can J Fish Aquat Sci 41: 1618-1625

Wildish DJ, Kristmanson DD (1997) Benthic suspension feeders and flow. Cambridge University Press, New York, NY

Wildish DJ, Kristmanson DD, Robinson SMC (2008) Does skimming flow reduce population growth in horse mussels? J Exp Mar Biol Ecol 358:33-38

Wiles PJ, van Duren LA, Häse C, Larsen J, Simpson JH (2006) Stratification and mixing in the Limfjorden in relation to mussel culture. J Mar Syst 60:129-143

Worcester SE (1995) Effects of eelgrass beds on advection and turbulent mixing in low current and low shoot density environments. Mar Ecol Prog Ser 126:223-232

Submitted: January 4, 2012; Accepted: May 9, 2012

Proofs received from author(s): August 15, 2012 